\title{
Reimagining Igbo Apprenticeship: Bringing it up to Speed with Contemporary Realities
}

\author{
N. Nnonyelu, C. Onyeizugbe
}

\begin{abstract}
The paper seeks to interrogate the practise and direction of Igbo apprenticeship, with particular interest in unravelling the reasons for the declining interest in apprenticeship generally among Igbo youths in South East, Nigeria. The paper is an exploratory, qualitative research paper premised on desk research encapsulating a comprehensive review of ethnographic and historical records while also utilising the observation method in informal workplaces and trading sites spread across diverse work settings. The findings indicate that the much talked about Igbo apprenticeship is facing significant challenges, and several factors have combined to demarket Igbo apprenticeship, making it less appealing to unemployed youths, with grave implications for unemployment, wealth creation and poverty reduction. Given the demand of the modern labour market, the paper calls for a hybrid model of apprenticeship that introduces in a more systematic manner, elements of traditional structure with a view to improving skill levels, job independence, higher remuneration, active engagement and sustenance of interest of all stakeholders.
\end{abstract}

Index Terms-Apprenticeship, Igbo, Informal Apprenticeship, Formal Apprenticeship, Reimagining, Repackaging.

\section{INTRODUCTION}

Historically, apprenticeships are the oldest forms of training in the world of work and business [23]. Its emergence predated the medieval era, when guilds, journey men and craftsmen flourished, setting the template for the exploitation of productive forces, and the corresponding relations of production. Despite the age old practise of apprenticeship, it did not receive adequate attention until recently. It seems that there is now a burgeoning of interest in apprenticeship generally [2], [7], [18], [19], [29], [32], [34], [36] and Igbo apprenticeship in particular [17], [24].This interest is not unconnected with the realization that apprenticeship, if properly harnessed may be the seedbed of a new spirit of enterprise and entrepreneurial culture that will mitigate the twin problems of spiraling unemployment and ravaging poverty [9]. Nigeria is touted to be the poverty capital of the world, with more than One hundred million Nigerians living on less than 2 dollars a day. Nigeria's problem is further compounded by the destructive effects of the novel Corona Virus Disease, commonly referred to as COVID-19 that has effectively brought the world to a standstill. In the developed

Published on June 2, 2020.

N. A. Nnonyelu, UNIZIK Business School, Nnamdi Azikiwe University, Awka, Nigeria.

(corresponding e-mail: aunnonyelu@yahoo.co.uk) western societies, the impact of COVID-19 has been huge and devastating, with some of the countries already sliding into recession, and also with unemployment figures beating all known records. In Nigeria, a mono-product economy, the effects will be colossal and mindboggling. Nigeria's Central Bank Governor, Emefiele Godwin has this to say about the current travails.

"The outbreak of the novel Corona Virus Disease, COVID19 in China has rapidly permeated and profoundly changed the world. Although, a public health issue which has claimed the lives as at today of over 123,000 people worldwide, and counting, the economic damages are unprecedented, stocks have fallen, oil prices dropped to lowest levels of 17 dollars a barrel, these have thrown the global economy into a recession. For mono product economies, the aftermath will be devastating" [11].

What the world has witnessed, at least for the first time in modern history is a decentering of the world akin to deglobalisation, where nation states shut down their borders, banned exports of all essential commodities, negating longstanding alliances and treaties of regional blocs. Even within nation states, component units also barricaded their areas in furtherance of social distancing, and stay at home policies refusing entry and exit routes. This goes to suggest that the future wellbeing of nation states and communities are premised on autochthonous initiatives such as having an allinclusive and diversified workforce that knows its onions as the agency of development.

Given this parlous state of the Nigerian economy, it seems within the remit of this paper to then consider novel ideas that will bring all sections of the populace into productive activities. One of the ways to realise this is to leverage on the apprenticeship scheme, so as to put many Nigerians back to work. The matter seems more urgent now given the increasing rate of unemployment [22]. Before the current job losses, the total number of people classified as unemployed rose to 21 million in Q3 of 2018 [22]. Unemployed refers to those between the ages of $15-64$ who are available, seeking for job, but cannot find any job [22]. Developed societies in Europe and America are reviewing the apprenticeship scheme with a view to improving and making the scheme more relevant. Apprenticeship scheme has since moved from the traditional/informal apprenticeship to incorporating formal aspects in line with the demands of labour market [8], [14]

C. U. Onyeizugbe, UNIZIK Business School, Nnamdi Azikiwe University, Awka, Nigeria.

(e-mail: edu_phd@yahoo.com) 
[37]. It is our view that the shrinking size of apprenticeship in Igboland, needs to be addressed, and redirected building on its foundation.

The Igbo, one of Nigeria's three main ethnic groups located within the South East and parts of South South regions of Nigeria, are described by [29] as naturally enterprising and ingenious. This description reinforces the observation by [21] who had valorised Igbo informal enterprises and its integrative roles in nation building. Others like [1], have also talked glowingly about the exceptionalism of the Igbo, even in the midst of very difficult historical challenges, including the almost three years Nigeria - Biafra Civil War, and [33] whose survey of small industries development in the eastern part of the country was inspiring.

The romantic picture painted above, may not be contextually right, currently, as indicators are rife that apprenticeship scheme in Igboland has suffered some reverses, and generally now on the decline, and this needs to be further interrogated with a view to revitalising the scheme. There is an ongoing doubt about the conitnued relevance and utility of the apprenticeship scheme in Igboland. Our thesis is that apprenticeship in Igboland has remained what it was in the 1960s and 1970s, and worse still, fears abound, that apprenticeship is currently facing a reversal. Given this backdrop, the objective of the paper is to explore the reasons for the seeming disinterest in apprenticeship, and, also examine factors considered germane to the revival and improvement of the Igbo apprenticeship scheme. This approach is buttressed by the seminal works of [8] in a study of apprenticeship in England. It seems to us that there has not been enough focus on the dangerous signals, besetting the apprenticeship scheme, in Igboland, that have made it unattractive to young persons and therefore, a complete paradigm shift in focus is required. This paper therefore takes as its point of departure the general narrative, which seems to be the new normal, that youths are no longer excited about, and interested in, apprenticeship. Why are youths in Igboland distancing themselves from apprenticeship, preferring to "walk the streets, stay idle, rather than devote substantial time to training or acquiring relevant skills?" Is the problem related to the narrow perception of apprenticeship as learning of manual, outmoded skills, or does it have to do with the structure of the apprenticeship scheme itself, or the ascendancy of a new perverted sense of values, where sudden wealth syndrome ("affluenza") of the nouveau riche and their ostentatious lifestyles have taken centre stage in the psyche of youths, and become barometers of status and social arrival? This paper therefore seeks to reimagine, and envision Igbo apprenticeship to bring the youths into the productive stream of the economy, while reducing the biting effects of unemployment and poverty. It is apposite that we have to first, establish the methodology that guided this paper and also seek conceptual clarity.

\section{Methodology}

The paper is essentially an exploratory research paper premised on desk research which encapsulates a critical analysis of relevant research papers and studies in apprenticeship [8], while also utilising the immense informal interactions/observations by the authors in informal sites dispersed across varied apprenticeship work places particularly in markets, mechanics, barbing and tailoring workshops. Therefore, this paper is premised on a comprehensive review of historic and ethnographic records [7] capturing Igbo ingenuity and entrepreneurship as demonstrated in the apprenticeship scheme.

\section{LITERATURE REVIEW}

\section{A. Understanding Apprenticeship}

Apprentice and Apprenticeship have been variously defined by different scholars. Apprentice refers to a person who learns a job or skill by working for a fixed period of time, for someone who is very good at that job or skill [3]. An apprentice is therefore one, in most cases, a teenager or young person who elects, or is persuaded to undertake or acquire practical, and in some cases, theoretical knowledge in a specialised area of interest, or occupation he/she would want to go into in future, or earn a living from. Apprentice refers to a person who has agreed to submit himself/herself within a period of time under the tutelage of a master/mistress, with the aim of acquiring practical, hands on, experience, and mastering the nitty-gritty of a trade, vocation or profession.

In some other climes, apprentice is seen somewhat differently, as a young person between the ages of 14 and 24 who is enrolled in and attending school, in case he/she has not completed secondary education, and enrolled in an apprenticeship programme [4]. The Brazilian characterisation of apprenctice highlights the different ways apprenticeship is perceived and treated in different societies.

Reference [14] defines apprenticeship as systematic long term training for a recognized occupation taking place substantially within an undertaking or under an independent craftsman, governed by a written a contract of apprenticeship, and is subject to established standards. Also, [28] identify apprenticeship as an effective mechanism for a seamless transition for young people to move from school to the world of work. To [9:6] apprenticeship is defined as a "unique form of vocational education combining job learning and school based training for specifically defined competences and work processes, regulated by law and based on written employment contract with a compensatory payment, and standard social protection scheme." Usually, certification follows the expiration of training where relevant certificates are awarded to successful apprentices. The foregoing definitions seem to exclude the type of apprenticeship prevalent in Igboland that are not affiliated to, or derived from Schools, or Colleges. Reference [2:26] looks at "apprenticeship as a job that includes training". This is too sweeping a definition, as it includes everything in employment circles as apprenticeship, whether it is training on the job, or off the job. In several societies, in Europe and America, emphasis is now on school and work based apprenticeship system, although the current trend is moving towards company based model [28] where the industry influences the pattern, character and content of 
apprenticeship. It is however Gonnon's definition that seems to mirror, or at least embrace apprenticeship, as it has been practised in Nigerian type societies, where [32] contends that apprenticeship is a mode of learning that focuses on acquiring specialised skills pursuant to getting young adults ready for work and society. Generally speaking, apprenticeship provides the apprentice specific opportunity "to get a foot in the door for future employment [9:12]. Given the fact that "apprenticeship system operates within the wider context of a country's cultural traditions, norms, socio-economic conditions and the aspirations of individuals [9:31] it is imperative that types of apprenticeship be established for a comprehensive view of apprenticeship.

\section{B. Types of Apprenticeship}

There are in the literature, three distinct types of apprenticeship, namely Traditional, Informal, and Formal [14] although most Euro-American commentators concentrate more on the formal apprenticeship, some even treating the informal apprenticeship as merely another form of work based learning, noting that all apprenticeships are work based learning, but not all work based learning are apprenticeships (see Table I below).

TABLE I: TYPICAL DIFFERENCES BETWEEN APPRENTICESHIP AND OTHER FORMS OF WORK BASED LEARNING

\begin{tabular}{|c|c|c|c|c|}
\hline & $\begin{array}{l}\text { Apprentices } \\
\text { hip }\end{array}$ & $\begin{array}{l}\text { Informal } \\
\text { Apprentices } \\
\text { hip }\end{array}$ & Internship & Traineeship \\
\hline $\begin{array}{l}\text { Tripartite } \\
\text { Governance }\end{array}$ & Yes & No & No & No \\
\hline $\begin{array}{l}\text { Remunerati } \\
\text { on }\end{array}$ & Yes & Possible & Probably & Possibly \\
\hline $\begin{array}{l}\text { Written } \\
\text { Contract }\end{array}$ & Yes & No & Possibly & Possibly \\
\hline $\begin{array}{l}\text { Social } \\
\text { Security } \\
\text { Cover }\end{array}$ & Yes & No & No & No \\
\hline $\begin{array}{l}\text { Legal } \\
\text { Framework }\end{array}$ & Yes & No & No & No \\
\hline $\begin{array}{l}\text { Programme } \\
\text { of Learning }\end{array}$ & Yes & No & No & Possibly \\
\hline $\begin{array}{l}\text { On The Job } \\
\text { Training }\end{array}$ & Yes & Yes & Yes & Yes \\
\hline $\begin{array}{l}\text { Off The Job } \\
\text { Training }\end{array}$ & Yes & No & No & No \\
\hline $\begin{array}{l}\text { Formal } \\
\text { Assessment }\end{array}$ & Yes & No & No & No \\
\hline $\begin{array}{l}\text { Recognised } \\
\text { Qualificatio } \\
\mathrm{n}\end{array}$ & Yes & No & No & No \\
\hline Duration & $1-4$ Years & Variable & $\begin{array}{l}\text { Up to } 12 \\
\text { Months }\end{array}$ & $\begin{array}{l}\text { Up to } 12 \\
\text { Months }\end{array}$ \\
\hline
\end{tabular}

Source: [14:7] in the basis of Steedman (2012)

It is clear from ILO classification and the affirmative responses given to the eleven key elements under the apprenticeship category that informal apprenticeships do not, strictly speaking, come under the canopy of apprentices. This, in our view, has not given sufficient consideration to the panoply of cultural cum environmental and other state factors that must be captured or brought into the metrics in the configuration of apprenticeships.

Reference [9] has however provided a useful categorisation of apprenticeship namely;
(1) Traditional: This is largely dependent on informal, oral agreements and is heavily attached to strong traditional rules and kingship, particularly in rural areas. These forms of apprenticeship do not include school based training [29]. Here also, apprenticeships are oftentimes subjected to very strict gender division.

(2) Informal: This is based on informal agreements and takes place in informal companies. Sometimes, the businesses are organised into guilds that act in the interest of their members. This form of apprenticeship is not usually complemented by school based training as in formal training institutions [9:12]. Reference [9] also alludes that in some cases, the craft master himself may not be sufficiently knowledgeable and therefore, transfers only a limited quality and scope of skills to their apprentices. In Nigeria, and among the Igbo, what largely obtains given the dominance of the informal economy, is the informal based apprenticeship model. The plethora of very small, micro, small and medium enterprises have received substantial encouragement (even though this could be improved) from the apprenticeship scheme [29]. Reference [23:683] captures the characteristics of informal apprenticeship thus

"In an informal apprenticeship, contracts between the master and the apprentice are not necessary (not existing or not followed), certificates are not recognized, governmental funding is not available, and the informal apprenticeship approach is not part of the National Vocational Education Training (VET) Policy."

The observations by [23], though largely correct fail to incorporate the symbolic underpinnings that inform the apprenticeship scheme among the Igbo. Given the fact that apprenticeship is not universal, but widespread [7] different historiographies and backgrounds need to be recognised in depicting what apprenticeship is really. It is also not inconceivable to have a coexistence of both the informal and formal systems of apprenticeship. We shall be exploring that in greater detail.

(3) Formal: This form of apprenticeship is a modern, formalized and well-structured form of learning [9], [34] is regulated by law, and a large period of the apprenticeship is carried out within the identified or selected company, while also alternating with the school environment. Reference [7:115] sees apprenticeship in a more generalised manner as a "formal contractual relationship between a master and a novice of a specific duration which is designed to serve two ends: provide cheap labour, and/or fees to support the master's enterprise, and to afford the apprentice an opportunity to learn and receive certification or mastery".

According to [37], in formal apprenticeships, there are other distinguishing features that delineate the operations namely; (a) Apprentices are registered, and are paid by employers during training, (b) Programmes meet national requirements or standards for registration, (c) Programmes provide on the job learning, and job related classroom or technical instruction, (d) On the job learning is conducted under the guidance of the employer or his representative, and (e) Training results in an industry recognised credential that satisfies occupational proficiency.

Given the foregoing, it is analytically useful to see 
apprenticeship from the perspective of [12:760] as a "mostly non-didactic way of teaching and learning grounded in a local context and dependent on the participation of the learner in work-related activities. Reference [12:760] further contends that "apprenticeship is not simply an educational context in which learners acquire technical skills, but a learning environment in which world views, ethical engagement, moral values in particular related to work, work identities, class, gender and the place and role of skilled workers in society, are shaped as part and parcel of the process of learning". At this juncture, it is apposite to examine the attributes of apprenticeship among the Igbo.

\section{Features of Igbo Apprenticeship}

Among the Igbo in South Eastern Nigeria, apprenticeship has a long history, was in existence before the arrival of the British Colonial masters, and has over the years shown some level of resilience. Some of the features include;

(a) Low Educational Level: Reference [34] argues that until recently, apprenticeship was meant for a person who had primary education or at best secondary school certificate, but could not for diverse reasons proceed for further studies. Therefore, a salient feature that one can deduce from Olulu \& Udeorah's assertion is the low educational level or background of the apprentices, which is even reinforced by their low socio-economic status. A majority of the apprentices, it would seem, come from very poor homes. This may be undergoing some changes given the rise in graduate unemployment.

(b) Diversity of Occupations: The other feature is the diversity of occupations that the apprentices are involved in. There seems however, to be a preponderance now of apprentices, in commerce, or precisely, large number are in the trading (buying and selling of goods and merchandise), while significant others are dispersed in other different occupations, and crafts like tailoring, brick laying, welding, painting, vulcanisers, barbing, fashion designing, blacksmithing, mechanics or car/bicycle repairs etc.

(c) Apprenticeship Contract is Traditional/Family Oriented: Another feature is the pervasiveness of customary or traditional contract relationships within the Igbo apprenticeship scheme. In Igboland, a parent or guardian chooses a trade or profession for the child or ward to learn, and also identifies a close member of the kin group or village who is reputable and knowledgeable in the chosen area for guidance [29]. Both parties discuss and enter into an agreement usually oral, whereby the intending apprentice and his/her family consent to serve the master/mistress, loyally, dutifully and conscientiously. This is largely seen in Igbo parlance as Igba odibo, Imu oruaka. This relationship, largely subservient is not at all restricted to the apprentice (" $n w a$ boyi") [17] and his master ("oga") [27] but involves their families. Even in the midst of the oral agreement, there used to be strong societal involvement that sustained the apprenticeship. This is largely fading away.

There are times however where symbolic payments are made to the master (some kind of tuition) [29] [34] which serves as a demonstration of interest and desire on the part of the family of the would be apprentice and a subtle recognition of the expertise, skills and knowledge of the master.

(d) Informality of the Apprenticeship Training: Given the lack of a formalised contract, and also the pervasive informality that is emblematic of Igbo apprenticeship scheme, it is not surprising to see a complete absence of a formal curriculum, what to be taught, and the exact content of training modules. In the absence of well laid out criteria, and pedagogical scrutiny, the apprenticeship scheme appears to be left in the hands of the master alone, and this becomes absolutist, if not arbitrary. There is a colossal absence of the state in the apprenticeship scheme in Igboland.

(e) Genderisation of Traditional Igbo Apprenticeship: Until very recently, apprenticeship was heavily skewed towards the male gender. Indeed the concept of nwa boyi and oga clearly illustrated that apprentices were reserved exclusively for the menfolk, or so it seemed, and same for the master craftsman or supervisor. Deep cultural beliefs and practices have tended to be the supporting scaffolds that somehow exclude the female gender from the apprenticeship scheme. Young women are often not aware of apprenticeship opportunities. In many countries, apprenticeships are centred around tradition, trades and crafts that are not appealing to young women [9]. This however, may require further empirical validation to determine its exact manifestation, patterns, dynamics, and complexion.

(f) Youth Dominance: Igbo apprenticeship scheme was youth oriented, cover mainly the age range from $12-25$ years. This is however not fixed or static, but one seldom hears of a forty year adult going into apprenticeship, in the traditional setting or context. This feature of Igbo apprenticeship has been brought forward and seems to resonate in several other countries as [9:6] observes that "in the face of large cohorts of unemployed youth and mismatches in skills and qualification levels, many countries wish to explore and introduce apprenticeship as a way to tackle youth unemployment and reduce future labour market imbalances. For the Igbo, apprenticeship strictly implies a training for young persons, under the guidance of older, more knowledgeable individuals, who sit in loco-parentis. It would therefore be abnormal for an elderly person to be seen undergoing apprenticeship in any vocation, as age is an important barometer in measuring life courses, or transitions. If it happens, it is largely a departure from the norm. This youth orientation is captured by [23] as young - person paradigm that situates the apprenticeship experience in terms of a relationship between an older person or group, and younger inexperienced person.

(g) Nursery of Igbo Entrepreneurship: One defining feature of Igbo apprenticeship is seen in its drive for the now famous Igbo entrepreneurial spirit. Apprenticeship in Igboland, is seen as the seedbed of the ethnic group's entrepreneurship [24], [29]. This is amply supported in the literature, as examples globally suggest, where human capital, especially through apprenticeships are crucial in creation of new businesses [13] and as evident in the works of [29] who enthused about the close proximity, or more precisely the determining influence of apprenticeship schemes on Igbo entrepreneurial culture. This is further buttressed in their assertion that: 
"The Igbo Trade Apprenticeship System provides an entrepreneurial network support system, and is an informal and unstructured training programme, scheduled for an agreed period, where a young person acquires desirable entrepreneurial skills, and are supported with startup capital at the end of the training" [29].

As a people, the Igbo traditionally loathe idleness, and this shows in the endurance of pain, which is immanent in apprenticeship [7]. The expectation of a promising future seems to be the tonic that sustains the interest of the apprentice while he goes through the excruciating experience, sometimes under the very cruel conditions of servitude.

There are some other characteristics of apprenticeship as generally categorised by [7:118 - 119] that also approximate the Igbo apprenticeship to some degree. These include: (a) Prominent use of punishment and abuse in training apprentices. The master enjoys some proprietary rights in enforcing discipline on the apprentices, (b) Hierarchical relationship between master and apprentice, a superordinate/subordinate relationship, where the labour of the apprentice is obligatory in order to tap from the expert wisdom of the master, (c) Tasks are laddered or arranged in stages, where the tasks are broken into component units, and the apprentice climbs the ladder, stage by stage, learning the simple, rudimentary tasks, before the complex and complicated ones, (d) Little active teaching, that emphasises its own distinct pedagogy premised on "learning by rote, imitation, observation, trial and error", (e) Lengthy and sometimes unsuccessful: apprenticeship is usually with a long duration, and at times not successful, (f) Keeping the master's secrets and love, where the apprentice must not be a loud mouth, be on his wit's end, use guile to open the treasury cove and obtain the vital information that underlies the profession or trade, and finally (g) Ends with a graduation ceremony this also obtains in traditional apprenticeships among the Igbo, where the apprenticeship ends with a ceremony known as Idu uno, in which case the master not only releases, or frees the successful apprentice with relevant occupational cum professional tools, materials, rent of a shop, and also cash. This is usually celebrated as the family of the apprentice, or representatives will join the master in this celebration where prayers are freely given, blessings are poured, and the guidance of God on the successful youngster is also solicited. These blessings are quite symbolic in many African cultures, as [7] also observed, and as Obidi had also highlighted earlier among the Yorubas [36].

\section{Challenges in Igbo Apprenticeship and Theoretical Orientations}

(a) Low value of the apprenticeship scheme

It does appear that apprenticeship in Igboland has not flourished, as one would expect owing to negative work ethics or low socio-cultural image of apprenticeships observed globally [9], [38] to the misperception in the public domain [34] that apprentices are children of low class families. It seems to us trite that such public demarketing of apprenticeship has kept many young adults that ordinarily would have been interested, out of the scheme. It is felt that the apprenticeship scheme is populated by not too bright individuals, academic failures [34], never do wells, which some Igbo villages refer to as "akologholi". In the distant past the success stories posted by the successful apprentices were significant wake up calls for their cohorts in the villages to lobby, or solicit through their families to be "recruited" as apprentices. They became role models, reference group and significant others, that copying them was a major boost of the apprenticeship scheme. This has theoretical support in the Social Learning Theory espoused by [35] and his followers which contends that people learn from one another through observation, imitation, even in creative ways and modelling.

Our thesis however, is that given the ascendancy of a new crop of money men, whose source of wealth is largely unknown, and who have taken over the public space as leaders in politics, economy, and in some communities as traditional rulers, it becomes then a major challenge to expect to witness the old passion and zeal in apprenticeship, which represents hard, diligent, honest, societally approved vocation that the Igbo were known for. It is this change in meaning, and perception that has contextually served to deincentivise people (young persons) from moving into apprenticeship. This may further be hampered by the lack of job prospects at the end of the training, may be occasioned by an economic downturn [9] as the one we are currently experiencing following COVID- 19.

(b) Lack of formal contract

Another major challenge that Igbo Apprenticeship has faced over the years is the absence of a clear formalised contract. Reference [25] expects that contracts of apprenticeship have to be written to subsist and be valid in law [26]. This is clearly not the case, as it seems to us reasonable to argue, that the attrition rate in apprenticeships may not be rosy, and this needs effective monitoring. In the absence of tight social bonds that will ensure that the master or " $O g a$ " respects the reciprocal relationship, or verbal agreements, the master has very easily found escape routes or the opportunity or convenient excuses not to "settle" the "nwa boyi" meaning not to equip the successful apprentice, and set him on his own journey of business and life.

(c) Lack of certification

Another challenge is the lack of certification which has greatly hampered the development of the Igbo apprenticeship scheme. One may argue that awarding certificates, or the undue emphasis on credentials, what is known as credentialism has been the bane of education in Nigeria, yet it seems incomplete for a training programme, vocational, or practical not to have evidence of having successfully completed a programme, and even the duration. This has been a major hindrance, making it difficult to separate the successful apprentices, and the uninitiated or untrained artisans.

(d) No harmonised curricula

Similarly, the content of the curricula may be another stumbling block. There are no mechanisms to check what is being taught, as some of the apprentices do more household chores, rather than what they have been brought to do, under the traditional, informal arrangement that still holds sway in Igboland, and in the diaspora, where the Igbo have 
emigrated plying their trade. It is this aspect that is worrisome, and it seems to us improper, as it could be very easily seen as modern slavery in disguise. It must be understood that the apprenticeship scheme is an exchange relationship, which the Social Exchange Theory has so clearly enunciated [10], [30], [31]. As [16] has contended, the exchange theory removes human interactions from the limitation of material transaction in an economic marketplace. Purely economic activities, are just a subset of broad, more generalized exchange relations in all social settings. In an economic market place, material goods characterise exchanges, whereas in other situations, human beings exchange other non-material commodities, such as sentiments and services of different hues [30]. In an exchange relationship, many things are involved, as [20:182] observed, we "exchange not only money and material goods, but also social goods - affection, security, prestige and information". Although, the apprenticeship relationship in Igboland is an unequal one, however, both parties expect something in return. It therefore cannot be skewed, or one sided, if it is going to be sustainable.

(e) Lack of governmental support

The apprenticeship scheme in Igboland is left entirely in the hands of the individual master or "employer" of the apprentice. No funds are made available to subsidize the training costs. The Nigerian state does not consider it necessary, has not seen the propriety of encouraging the apprenticeship scheme to succeed and transform itself. Any success of Igbo apprenticeship, or even entrepreneurship across the divide in Nigeria has to be rightly placed in the doorstep of individuals who have cultivated bridges of "friendship, marriage, commercial ... cooperation [6:33]. Similarly, [21:37] had this to say

"While Igbo informal enterprise was tolerated by the colonial government, it was given little encouragement, and no real support. After Nigerian independence in 1960, Igbo informal traders and producers became even more marginalized in the face of state efforts to promote the development of the formal economy".

Needless to say this marginalization has continued till this day. The lack of support from the Nigerian state is understood in the light of the prebendal, patrimonial and rentier character of the state. What is more perplexing however is that the component units, the states within the South Eastern region and Local Governments therein have also not paid any heed to what is happening in the world of apprenticeship. It is this official neglect of apprenticeship that is in our view, the singular, most important factor that has affected the Igbo apprenticeship scheme, and stopped it from flourishing.

\section{FINDINGS}

\section{A. Repackaging Igbo Apprenticeship Scheme}

The preceding discussions highlighting the challenges afflicting Igbo apprenticeship system bring to the fore the need to tackle headlong those roadblocks militating against the evolution and improvement of the scheme. A combination of factors have been identified in the preceding pages as responsible for the stagnation in apprenticeship. These include, low value of the apprenticeship system, degrading of the products of the scheme as mainly fit for manual work, or artisans, existence of verbal contract, now observed only in the breach, lack of certification and non-harmonised curricula, high attrition rate and lack of governmental support. We seek to demonstrate further that addressing the aforestated factors will rekindle interest in apprenticeship in Igboland.

Although the momentous achievements of Igbo apprenticeship scheme over the years have been documented in the literature, the changing dynamics, and the future of work, and declining interest in apprenticeship call for repackaging of the whole Igbo apprenticeship scheme. Following [18], apprenticeship needs to be redefined to broaden its remit and extend it to a large number of contexts and situations. Except this repackaging comes into full swing, it is difficult to accept the thesis by [29] that the apprenticeship scheme is pivotal in emplacing the Igbo at the centre of Nigerian manufacturing, transportation, and forwarding and backwarding sectors. We therefore recommend as follows

(1) State involvement in promoting apprenticeship

The apprenticeship scheme as currently practised needs to have substantial encouragement from Federal and State governments. The government should come out with a blueprint that specifically focuses on the apprenticeship schemes or practises nationally, although giving due attention to regional specificities or variations. Funding support is key to the sustenance of apprenticeship. It is no longer tenable to allow the master who hires an apprentice, or is made to have one, to bear the cost of the apprenticeship scheme. Tax rebates outside other concessions should be given to encourage the apprenticeship scheme. The role of government needs to be more prominent in reviewing the legislation on the provisions of [25] with respect to the burning issue of apprenticeship. It is our opinion that even in the midst of informality of apprenticeships in Igboland, the incorporation of clearly established formal contracts will not undermine the practise, but strengthen apprenticeship. This is also strongly recommended by [15]. What we have in place as the law on apprenticeship is not only scanty, but largely observed in the breach.

(2) Public enlightenment and awareness

There is need to have a systematic, well planned sensitisation programme that is geared towards promoting apprenticeship, and encouraging young persons to take to apprenticeship as a vehicle to making themselves employable in the labour market, particularly in the light of the shrinking size of government revenue owing to dwindling oil revenue. The Nigerian Directorate of Employment, and its parent ministry - the Ministry of Labour, Employment and Productivity should focus on this sensitisation programme. There is also need to involve other critical stakeholders in this new evangelisation of changing the narrative, and making apprenticeship attractive to members of the Organised Private Sector (OPS), Manufacturers Association of Nigeria (MAN), Nigerian Association of Chambers of Commerce, Industry, 
Mines and Agriculture (NACCIMA), Market Traders Association, Trade Unions and Cooperative Societies etc. Utilising the different social media devices as well as traditional communication tools should be very effective.

(3) Access to relevant education and curriculum review

It is expected that young persons in apprenticeship should be provided with relevant technical education. Reference [15] also recommended the introduction of new skills to upgrade the informal apprenticeship. Vocational and technical colleges may be sited within the markets, or other places that enjoy proximity to the different apprenticeship sites. As [5] observed, the education system needs to guarantee the skill profiles required by the labour market to enhance employability of young people, and this could be done through public private partnerships in the provision of Vocational and Technical Colleges. These Vocational Centres could be utilised by University graduates many of whom can no longer secure employment, and have swollen the ranks of the unemployed. Reference [9:37] notes that "retraining unemployed university graduates through apprenticeship for technical occupations (...) could provide affected countries and opportunity to take steps towards establishing apprenticeship opportunities to address this segment of youth. A well-reviewed curriculum and school based training with certificates on successful completion of training will go a long way to complement the current style of Igbo apprenticeship. This will also have, perhaps, the unintended consequences of increasing the esteem of the participants, their sense of self-worth, and status. It seems to us, that there is nothing inherent either in the definition of traditional or informal apprenticeships, or in its structure, that obstructs it from being upgraded, improved upon, and made more mutually rewarding to all parties. The paper calls for a more expansive view of Igbo apprenticeship to enable it realise its full potentials in a sustainable manner, against the increasingly changing dynamics of the labour market and the business environment. Rebranding the Igbo apprenticeship will in our view, be a game changer, and transform it from where it is today, a second choice option, to a preferred mode of self-improvement.

The British government took deliberate steps to change the perception of the apprenticeship scheme. As cited in [8:234], the British Prime Minister once observed

"by making apprenticeship a gold standard option, for ambitious young people, we are sending a message that technical excellence is as highly valued as academic prowess."

To make the Igbo apprenticeship system, remain competitive in the future, it is necessary to adapt the recommendations of ILO, who in 2017 developed six building blocks in its "Toolkit for Qualitative Apprenticeship", namely a robust regulatory framework, equitable funding arrangements, meaningful social dialogue, strong market place, clear roles and responsibilities and inclusiveness.

\section{CONCLUSIONS AND IMPLICATIONS}

Apprenticeship scheme in Igboland, South Eastern Nigeria, has generated a great deal of interest. This exploratory paper focused on the general direction of Igbo apprenticeship scheme and highlighted the causative factors that have served to de-incentivise the apprenticeship scheme leading to considerable lack of interest by different stakeholders, and moreso, desertion of the scheme by young adults. We also observed that the low status, low morale of apprentices and apprenticeships, its limiting outcomes in today's modern world of work, the lack of government involvement in promoting apprenticeship on a systematic, rather than the haphazard tokenistic interventions, the alienation between apprenticeship and school based learning, including the apparent lack of improved curriculum and relevant pedagogy, and the lack of binding contracts, have all contributed to the gradual deterioration of the apprenticeship scheme. The paper also highlighted that the dominance of a new perverted sense of values that romanticises materialism, or its worst form, unbridled acquisition of wealth, since the 1990s, have undermined the traditional predilection of Igbo Social Structure, exemplified in hard work, and honest pursuit of decent livelihoods. The emergence of new money men whose source of wealth is unknown, and the youth's perception of these group of people as role models, goes against traditional Igbo values and institutions, and attacks poignantly the edifying bedrock of Igbo apprenticeship system. However, in view of the methodological limitations, and given the exploratory nature of the paper, there are implications for further studies on the roles of the apprenticeship scheme in the creation of small enterprises in emerging economies in sub-Saharan Africa.

\section{IMPLICATIONS FOR POLICY AND PRACTISE}

The observations and finding made in this paper call the attention of the state (including national and state governments) to create the enabling environment for the apprenticeship scheme to flourish. A direct intervention in the upgrading of the apprenticeship scheme, increasing the general skill levels, and supporting massively through injection of funds may be a panacea to the observed flaws in the system. It requires a complete paradigm shift in the organisation of the apprenticeship system through relevant statutory provisions. It is the contention of the paper that the current hiatus or disconnect between informal and traditional Igbo apprenticeship scheme and the formal based apprenticeship has policy implications to address the complexities of the skills gap in the Nigerian labour market. This conclusion has support in the observations by [8:228] that

"apprenticeship can suffer not only from the historical widely held view of what an apprenticeship is/was, but also from criticism aimed at how they function, who they are designed for/aimed at, and what they achieve. It is widely presumed that apprenticeships are ... only available in manual occupations"

A more expansive view of apprenticeship involving lawyers, 
doctors, pharmacists, teachers, etc shall improve the standing of apprenticeship generally.

\section{IMPLICATIONS FOR FURTHER STUDY}

This study has exposed the need to have a broader and more comprehensive study of the changes, evolving patterns and continued prospects of Igbo apprenticeship scheme. It has become necessary that further studies shall focus on the recruitment processes undergirding the current informal apprenticeship scheme, rate of turnover, or attrition in different workplaces, expected outcome and potential benefits. A triangular methodological approach that utilises the quantitative and qualitative approach may be a further improvement on the current paper. It is our opinion, that an apprenticeship duality is feasible in the light of emerging current work realities, and this should capture the attention of further research.

\section{REFERENCES}

[1] A. Harniett - Sievers, Construction of Belonging: Igbo Communities and the Nigerian State in the Twentieth Century, Rochester: University of Rochester Press, 2006.

[2] A. Vareto, "Apprenticeships: What you need to know," Nurs Manaj, vol. 24 , no. 7, pp. $26-37,2017$.

[3] Apprentice. (2020). In Merriam-Webster.com. Retrieved April 22, 2020, from https://www.merriam-webster.com/dictionary/apprentice

[4] Apprenticeship Manual: What You Need to Know to Hire an Apprentice, Brazil Ministry of Labour and Employment, 2013.

[5] C. G. E. Salami, "Entrepreneurship and youth unemployment in Nigeria: The missing link," Global Journal of Management and Business Research, vol. 2, no. 5, pp.21 - 26, 2011.

[6] D. Anthony, Poison and Medicine: Ethnicity, Power and Violence in Nigerian City, 1966 - 1986, Oxford: James Currey, 2002.

[7] D. F. Lancy, "First you must master pain: The nature and purpose of apprenticeship," Anthropology of Work Review, vol. 33, no. 2, pp.113 $-126,2012$.

[8] D. Lee, "Apprenticeships in England: An overview of current issues," Higher Education, Skills and Work-based Learning, vol. 2, no. 3, pp. $225-239,2012$.

[9] Delivering TVET through Quality Apprenticeships. Bonn, Germany: UNESCO - UNEVOC International Centre for Technical and Vocational Education and Training, 2015.

[10] G, Homans, Social Behaviour: Its Elementary Forms, New York: Harcourt Brace, 1974.

[11] G. Emefiele, "Turning COVID-19 tragedy into opportunity for new Nigeria," an opinion piece presented at the Central Bank of Nigeria (CBN) Headquarters, Abuja, April 15, 2020.

[12] G. Gowlland, "Apprenticeship as a model for learning in and through professional practise," in International Handbook of Research in Professional and Practise Based Learning, S.B. Ilet et al, Eds. 2014, pp. $257-779$.

[13] H. S. Lee and S. Chang, "Environmental jolts, internal buffers and failures versus survivals of high technology based ventures," presented at BKERC, Boston, Massachusetts, June 8-11, 2005.

[14] ILO Toolkit for Quality Apprenticeships, Vol. I: Guide for policy makers. Geneva, Switzerland: International Labour Organisation, 2017.

[15] Improving Informal Apprenticeship. Geneva, Switzerland: International Labour Organisation, 2011.

[16] J. A. Turner, The Structure of Sociological Theory, Illinois: Dorcey Press, 1978.

[17] J. K. C. Onyima, H. N. Nzewi and O. M. Obiekezie, "Effects of apprenticeship and social capital on new venture business creation process of immigrant entrepreneurs," Review of Public Administration and Management, vol. 2, no. 3, pp.1 - 11, 2013.

[18] J. Lave and E. Wenger, Situated Learning: Legitimate Peripheral Participation, Cambridge: Cambridge University Press, 1991.

[19] J. Singleton, "Japanese folkcraft pottery apprenticeship: Cultural patterns of an educational institution," in Apprenticeship: From Theory to Method and Back Again, M. W. Coy, Ed. New York: Suny Press, pp.13-30, 1989.

[20] J. Zanden, The Social Experience: An Introduction to Sociology, US: McGraw Hill, 1990.

[21] K. Meagher, "The informalisation of belonging: Igbo informal enterprise and national cohesion from below," African Development, vol. 34, no. 1, pp.31-46, 2009.

[22] Labour Force Statistics, Vol. I: Unemployment and underemployment report (Q4 2017 - Q3 2018). Abuja, Nigeria: National Bureau of Statistics, 2018.

[23] M. Gessler, "Concepts of apprenticeships: Strengths, weaknesses and pitfalls," in Handbook of Vocational Education and Training, McGrath et al, Eds. Switzerland: Springer Nature, 2019.

[24] N. O. Madichie and A. D. Nkamnebe, "51, Iweka Road, Onitsha, Nigeria: Could this single African address redefine business cluster development?" World Review of Entrepreneurship Management \& Sustainable Development, vol. 6, no. 3, pp.229 - 243, 2010.

[25] Nigerian Labour Act, Section 50 (1), 2004.

[26] O. Amucheazi and E. Orji, "A critical analysis of apprenticeship contracts under Nigerian law," Labour Law Review, pp.1-16, 2009.

[27] O. V. C. Okene, Labour Law in Nigeria: The Law of Work, Port Harcourt, Nigeria: CDC Publishers, 2011.

[28] OECD - ILO. (April 2020). Engaging employers in apprenticeship opportunities [Online]. Available: http://dx.doi.org/10.1787/9789264266681-en

[29] P. A. Igwe, R. Newberry, N. Amoncar, G. R. T. White and N. O. Madichie. (2018). Keeping it in the family: Exploring Igbo ethnic entrepreneurial behaviour in Nigeria. International Journal of Entrepreneurial Behaviour and Research [Online]. Available: https://doi.org/10.1108/IJEBR-12-2017-0492.

[30] P. Blau, Exchange and Power in Social Life, New York: Wiley, 1964.

[31] P. Eke, Social Exchange Theory: The Two Traditions, London: Heineman, 1970.

[32] P. Gonnon, "Apprenticeship as a model for the international architecture of TVET," in Assuring the Acquisition of Enterprise: Apprenticeship in the Modern Economy, Z. Zhao, F. Rauner, U. Hauschildt, Eds. Beijing: Foreign Language and Research Press, 2011, pp. $33-42$.

[33] P. Kilby, The Development of Small Industries in Eastern Nigeria. Lagos: Ministry of Commerce USAID, 1963.

[34] R. M. Olulu and S. A. F. Udeorah, "Contract of apprenticeship and employment generation in Nigeria". International Journal of Scientific Research in Education, vol. 11, no. 3, pp.335 - 344, 2018.

[35] S. Bandura, Social Learning Theory, New York: General Learning Press, 1991.

[36] S. S. Obidi, "Skill acquisition through indigenous apprenticeship: A case study of the Yoruba blacksmith in Nigeria," Comparative Education, vol. 31, no. 3, pp.369 - 383, 1995.

[37] The Benefits and Costs of Apprenticeship: A Business Perspective. US Department of Commerce, Ohio: Case Western Reserve University, 2016.

[38] Upgrading Informal Apprenticeship: A Resource Guide to Africa. Geneva, Switzerland: International Labour Organisation, 2012. 